\title{
Quantitative Ethnobotanical Investigation Of Flowering Plants of Laspur Valley (Chitral), Pakistan
}

\author{
Ghulam Qadir*, Jan Alam, Manzoor Hussain, Ghulam Mujtaba Shah, Ghazala \\ Shoab and Inayat Ur Rahman \\ Department of Botany, Hazara University Mansehra-21300, KP, Pakistan
}

E-mail: hu.qadir77@gmail.com

Received: 25.11.2019. Accepted: 10.12.2019

\begin{abstract}
The use of medicinal plants for treatment, cure and prevention of diseases has been described by many people since time immemorial. Because of this, the scientific interests have emerged, making it necessary to realize ethnobotanical surveys of plants species, which is important for subsequent phytochemical and pharmacological bio prospections. This paper deals with the indigenous uses of 44 flowering plants of Laspur Valley, District Chitral. These species distributed in 26 families and 42 genera. Asteraceae was the largest family with 6 species (14.89\%), followed by Rosaceae with $4(8.51 \%)$ species. In the rest of families, less than 3 species $(6.38 \%)$ per family were recorded. Leaves of 6 plants were used for medicinal purposes. Similarly, roots of 24 species and fruit / flowers of 6 species were used, while 24 species were used as whole plant and seed of six were used for different purposes. About 30 species were as fodder, 26 medicinal purposes, 7 for hatching, 7 as fire wood, 5 as timber, 5 as vegetable, 3 fencing, 3 furniture 5 agricultural purposes while 4 used for making handy craft instrument. Further, the study is required to quantify the availability of plants which are important traditionally for various purposes. The pressure on natural resources increases day by day which further led the local floral diversity to destruction. The conservation strategies must be implemented in the study area to save the God gifted natural wealth.
\end{abstract}

Key words: Biodiversity; Ethnobotany; Traditional Uses; Laspur Valley; Chitral

\section{Introduction}

The uses of plant are earlier as the arrival of human in the earth but their uses were restricted. Passage of time due to increasing of daily requirement of human uses of plants was increased gradually because their dependency increases directly or indirectly. Most of the plants are cleared due to increasing in the population for building and houses and other requirement like road, playground etc. The plant also affected due to their potential such as medicinal value. The traditional medicines are used by the people are since long (Lema et al., 2001; Partel et al., 2005). The uses of pant for curing is very old tradition but still now a day's people believe in traditional uses of medicinal plants (Ali \& Qaiser, 2009). According to an estimate the developing countries about 70 to $80 \%$ plant species using for their primary health care (Frainsworth \& Sorjarto 1991). But according to current estimate the use of traditional medicine is decreased in develop countries (Titz, 2004). Pakistan with rich plant biodiversity of vascular species due to varied climatic and edaphic factor unfortunately in Pakistan there is no any comprehensive report related to the vegetation flora of Chitral. The British medicine officer Giles in 1984-85. first time intrudes plant in Chitral then Younghusband (1894) Duthie (1998), first person to publish check list of plant of chitral based on collection made by British officer relief expedition 1993 (Ali, 2009 ). For Pakistan 1572 genera 5521 species identified (Ali, 2008). Most of which are confined to mountain areas (Ali \& Qaiser, 1986). Hussain (2003) reported enthno botanical information of 19 fruit plant and Hussain et al. (2007) indicate 111 plants of Mastuj. Similarly, Ali and Qaiser (2009) documented detailed on ethno botany of chitral valley from varies locality about 11 articles have been published on 270 species number of family are 85, genus 114 among them 220 are wild and 50 species are cultivated while just two species are collected by Qaiser from current study area but no intensive studies have been reported on Laspure valley. Some work has been carried by Khan et al. (2011) on the important medical plant of Chitral gol national park and Shaheen et al. (2012) on photo diversity and endemic richness of Qurumbar lake vegetation of Chitral, but no anyone are them reported traditional medical uses of plant from valley Laspur Chiral. Present studies document indigenous information regarding ethno botanical study of 44 flowering plant of Laspur valley. Chitral District is in the extreme North East of the Khyber Pakhtunkhwa province (KP) Pakistan. It lies within $35^{\circ} 15^{\prime} 06^{\prime \prime}$ to $36^{\circ} 55^{\prime} 32^{\prime \prime}$ North and $71^{\circ} 11^{\prime} 32^{\prime \prime}$ to $73^{\circ} 51^{\prime} 34^{\prime \prime}$ East with a population 320,000 (Anon., 1998). It is a beautiful valley in Hindukush range of mountains it has always been a very important route for many invaders to south Asia including Alexander the great scynthians, Mangol Changez and numerous other, you can get Chitral from Peshawar or Swat via Dir through Lawari tunnel and from Gilgit through phandar Shandur pass. Chitral is a land with very rich floral diversity due to its unique geographical position (Ali \& Qaiser, 1986). Phytogeographically, the District Chitral falls under Eastern Irano-Turanian region (Ali \& Qaiser, 1986). 


\section{Study Area}

Laspur valley is situated upper part of district chitral at the distance of $120 \mathrm{~km}$ from chitral city. Occupied area of valley is about 640 sq km with 1385 hacter crop land. It is bordered as with ghazer (GB), Kalam (Swat), west Musharbat mountain (Boni Zoom), North Mastuj and south Komrad (Dir upper). Administratively it comes under union council Laspur tehsil Mastuj. Population is about 12000 (Ann, 1998 and BISP, 2011). Valley Laspur comprise six main villages namely Gasht, Raman, Harchin, Broke, Balim and Sour Laspur. The world highest polo ground located in Shandur valley Laspur and big kachikani pass is also in Laspur valley which is gate way for tourist between Chitral and Swat. Climatically it comes under arid temperate zone with high snow fall sever winter pleasant summer (Hussain, 2003). June, July and August hottest month of the year while December, January and February are coldest month of the year. The best session for plant collection is May to end of September (Ali \& Qaiser, 2005-2007).

\section{Materials and Methods}

To find out the traditional uses of medicinal plant first, thorough relevant literature reviewed. Based on literature-survey, a comprehensive field plan was prepared in order to collect information and specimens. The field survey conducted in study area from May to July in lower area of Laspur while in Shandure and Bashqargole July to September is favorable session for plant collection. The following information are collected: For accurate position of the species, G.P.S coordinates recorded at the selected sites during collection of plant specimen. Specimens collected in Polythene bags and a separate collection number given for each specimen. For data collection, semi-structured questionnaire was used with modification following Ali \& Qaiser (2009). The medicinal value, part used asked from the local people especially old age people are focused. Other important parameters like habitat, habit, and flower color, altitude etc. also Photographs taken especially focusing habitat, habit, flower and fruit. Specimen poisoned in the mixture solution of alcohol, copper sulphate, phenolic crystals and mercuric chloride. Stereoscope was used to examine the collected species, digital camera used for capturing picture of specimen. Collected material identified with the help of flora of Pakistan (Nasir \& Ali, 1970-1989; Ali \& Nasir, 1989-1992; Ali \& Qaiser, 1993-2000). Finally, voucher specimens deposited in Herbarium Hazara University, Mansehra Pakistan (HUP).

\section{Results and Discussion}

The study indicates that there were 44 plant species divided into herbs (72.72\%), shrubs (13.63\%) and trees (13.63\%) used for different purposes (Figure 1). Our findings are congruent with many researchers of allied, neighboring and national regions (Ijaz, 2014; Ijaz et al., 2015; Khattak et al., 2015; S.M. Khan et al., 2015; K.U. Khan et al., 2015; Shah et al., 2015; Ahmad et al., 2016 and Rahman et al., 2016a). Total 44 plant species are distributed among 25 families. Asteraceae was the family with species (13.64\%), followed by Lamiaceae and Rosaceae species each with 4 (9.09\%). Iqbal et al. (2015); Ijaz et al. (2016) and Shaheen et al. (2016) also reported Asteraceae as the most leading family.

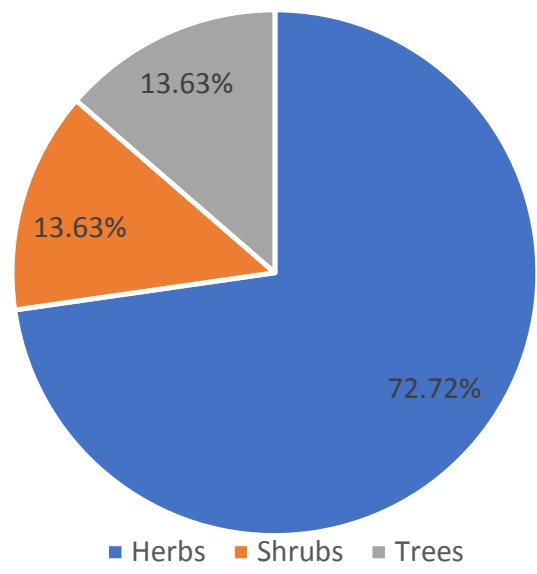

Figure 1. Plant habit percentage of the medicinal species recorded from the study area.

While in rest of 22 families, less than 4 species have been reported. Whole plant $24(54.54 \%)$ was most frequently used in the study area for health services, followed by leaves of $6(13.63 \%)$ plants were used for medicinal purposes. While contradictory results were reported by Ijaz (2014); Ijaz et al. (2015) and Ijaz et al. (2016). They noticed leaves as the most useful plant part for medicinal values. However, roots of $4(9.09 \%)$ species, fruit/flowers of $6(13.63 \%)$ species and bulb of $4(9.09 \%)$ species were used for the treatment of different diseases (Figure 2). About $31(70.45 \%)$ species were as fodder, 26 (59.09\%), 5 (11.36\%) for hatching, $14(31.88 \%)$ as fire wood, $14(31.88 \%)$ as timber, $5(11.36 \%)$ as vegetable, $7(15.90 \%)$ fencing, 3(6.81\%) furniture 5 $(11.36 \%), 6(13.63 \%)$ agricultural purposes while $3(6.81 \%)$ used for making handy craft instrument. Dominated medicinal plants with high used values were Juglans regia $(\mathrm{UVi}=0.96)$, Cappris spinosa $(0.88)$ and Allium cepa (0.87). Agreed results were reported by Rahman et al. (2016b) who also mentioned Juglans regia as the most dominated medicinal plant species with used values (UVi= 0.94). Based on the RFC values, the most valuable and cited medicinal plant species used by the traditional drivers are Juglans regia having (RFCs=0.48) and Cappris spinosa (0.46). Similar findings were reported by Rahman et al. (2016b,c) regarding medicinal plant species RFCs values. They cited Juglans regia with most RFCs $=0.69$ value. CI results show that most respondents percentage was for Juglans regia having $\mathrm{CI} \%=48 \%$, used for irritated eyes, skin disease, dental problem and furniture followed by Cappris spinosa L. (46\%) for typhoid, asthma and blood purifier. Based on CI\% results, Rahman et al. (2016b) reported exact findings [Juglans regia $(\mathrm{CI}=69 \%)$ ]. The study area is control of heavy biotic pressure due to unsustainable use plant species like deforestation, grazing animal and unawareness of local people in medical plant collection, which has increased soil erosion. Many species, such as Betula utilis, rapidly reduced over the past few year, most of plant are use as timber wood and fire wood.as the people of the area are use plant for curing various diseases therefore loss of these plant will result reduction of health system of 
pour people of the area it necessary of the time to promote measure for conservation of God gifted resources particularly medicinal plant of the Laspur valley, Chitral. Majority of medicinal plant species were used in treatment of cough 13 (29.54\%), asthma 11 (25\%) whereas and lowest percentage of species were used for anthelmintic as well as increasing intelligent power 2 (4.54\%). All the diseases were treated orally except skin problems as reported by many other researchers (Upreti et al., 2010; Lulekal et al., 2013; Luitel et al., 2014; Rahman et al., 2016a, b).

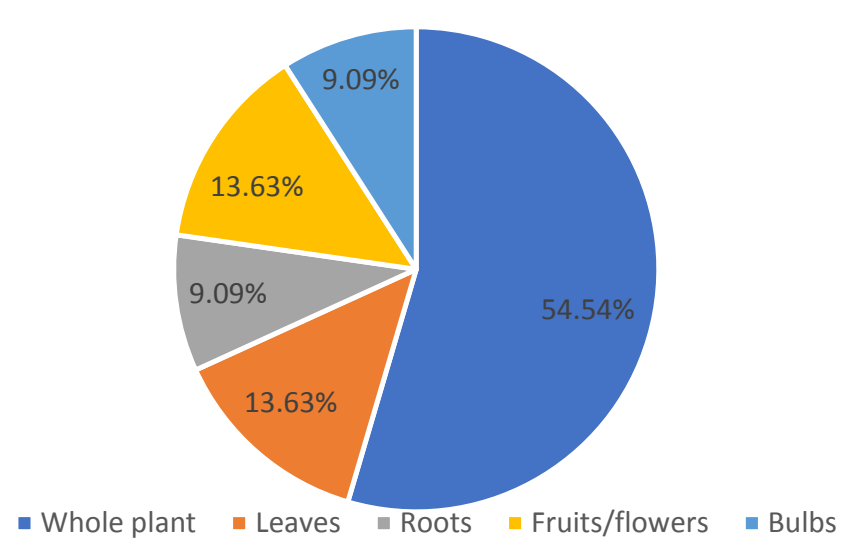

Figure 2. Medicinal plant parts used by the local inhabitants of the study area in the treatment of various diseases.

\section{References}

Ahmad, Z., Khan, S.M., Ali, S., Rahman, I.U., Ara, H., Noreen, I., Khan, A. (2016). Indicator species analyses of weed communities of maize crop in district Mardan, Pakistan. Pakistan Journal of Weed Sciences Research, 22(2): 227-238.

Ali, H., Qaiser, M. (2009). The ethno botany of Chitral Valley, Pakistan with particular reference to Medicinal plants. Pakistan Journal of Botany, 41(4): 2009-2041.

Ali, S. I., Qaiser, M. (1986). A phytogeographical Analysis of Phanerogams of Pakistan and Kashmir. Proc. of Royle Soc. Edinburgh, 898:89-100.

BISP survey report (2011). Survey of Pakistan map, Department of Agriculture census and Union council Laspur record.

Fransworth, N.R., Soejarto, D. D. (1991). Global importance of medicinal plants. In: O., Akerele, V. Heywood and H. Synge, (Eds.): The conservation of medicinal plants: Proceedings of an international consultation 21-27 March 1988, Chiang Mai, Thailand Cambridge University Press, Cambridge, 25-51.

Hussain, F. (2007). Traditional resource evaluation of some plants of Mastuj, District Chitral, Pakistan. Pakistan Journal of Botany, 39(2): 339-354.

Hussain, F., Murad, A., Durrani, M. J. (2004). Weed communities in the wheat fields of Mastuj, District Chitral, Pakistan. Pakistan Journal of Weed Sciences Research, 10: 101-108.

Hussain, F., Sher, H., Ibrar, M. (2004). Ethno medicinal profile of some plants of District Swat, Pakistan. Pakistan Journal of Plant Sciences, 10: 85-104.

Ijaz, F., Iqbal, Z., Rahman, I.U., Khan, S.M., Shah, G.M., Khan, K., Afzal, A. (2016). Investigation of traditional medicinal floral knowledge of Sarban Hills, Abbottabad, KP, Pakistan. Journal of Ethnopharmacology, 179: 208-233.

Ijaz, F., Iqbal, Z., Alam, J., Khan, S.M., Afzal, A., Rahman, I. U., Afzal, M., Islam, M., Sohail. (2015). Ethno medicinal study upon folk recipes against various human diseases in Sarban Hills, Abbottabad, Pakistan. World Journal of Zoology, 10(1): 41-46.

Ijaz, F. (2014). Biodiversity and traditional uses of plants of Sarban Hills, Abbottabad. M. Phil. Thesis, Hazara University Mansehra, KP, Pakistan.

Iqbal, M., Khan, S., Khan, M.A., Rahman, I.U., Abbas, Z., Zahidullah. (2015). Exploration and inventorying of weeds in wheat crop of the district Malakand, Pakistan. Pakistan Journal of Weed Sciences Research, 21(3): 435-452.

Khan, K.U., Shah, M., Ahmad, H., Ashraf, M., Rahman, I. U., Iqbal, Z., Khan, S.M., Majid, A. (2015). Investigation of traditional veterinary phytomedicines used in Deosai Plateau, Pakistan. Global Veterinaria, 15(4): 381-388.

Khan, S.M., Din, N.U., Sohail, Rahman, I.U., Ijaz, F., Iqbal, Z., Ali, Z. (2015). Ethnobotanical study of some medicinal plants of Tehsil Kabal, Distrct Swat, KP, Pakistan. Medicinal Aromatics Plants, 4(3).

Khattak, N.S., Nouroz, F., Rahman, I.U., Noreen, S. (2015). Ethno veterinary uses of medicinal plants of district Karak, Pakistan. Journal of Ethnopharmacology, 171: 273-279.

Lama, Y.C., Ghimire, S. K., Aumeeruddy-Thomas, Y. (2001). Medicinal plants of Dolpo: Amchi's knowledge and conservation. WWF Nepal Program, Kathmandu, Nepal.

Rahman, I.U., Ijaz, F., Afzal, A., Iqbal, Z., Ali, N., Khan, S. M. (2016). Contributions to the phytotherapies of digestive disorders; Traditional knowledge and cultural drivers of Manoor Valley, Northern Pakistan. Journal of Ethnopharmacology, $192,30-52$.

Rahman, I. U., Ijaz, F., Iqbal, Z., Afzal, A., Ali, N., Khan, M.A., Afzal, M., Muhammad, S., Qadir, G., Asif, M. (2016). Graphical dataset on important medicinal plants used for curing dental issues in Manoor Valley, Mansehra, Pakistan. Data in Brief, 9, 10281033.

Rahman, I.U., Ijaz, F. Z., iqbal, Afzal, A., Ali, N., Afzal, M., Khan, M. A., Muhammad, S., Qadir, G., Asif, M. (2016). A novel survey of the ethnomedicinal knowledge of dental problems in Manoor valley (Northern Himalaya) Pakistan, Journal of Ethnopharmacology, $194,877-894$.

Shah, A.H., Khan, S.M., Shah, A.H., Mehmood, A., Rahman, I.U., Ahmad, H. (2015). Cultural uses of plants among Basikhel Tribe of District Tor Ghar, Khyber Pakhtunkhwa, Pakistan. Pakistan Journal of Botany, 47(SI): 23-41.

Shaheen, S., Iqbal, Z., Ijaz, F., Alam, J., Rahman., I.U. (2016). Floristic composition, biological spectrum and phenology of Tehsil Havelian, District Abbottabad, Pakistan. Pakistan Journal of Botany, 48(5): 1849-1859. 
Titz, A. 2004. Medicinal herbs and plants scope for diversified and sustainable extraction. 22-26.

\section{Citation:}

Ghulam, Q., Jan, A., Manzoor, H., Ghulam, M. S., Ghazala, S., Inayat, U. R. (2019). Quantitative ethnobotanical investigation of flowering plants of Laspur Valley (Chitral), Pakistan. Ukrainian Journal of Ecology, 9(4), 561-564.

(cc) $\mathrm{EY}$ This work is licensed under a Creative Commons Attribution 4.0. License 